\title{
ITALIAN CONTRIBUTION TO CSP WITH FLAT OR ALMOST FLAT REFLECTORS
}

Cesare Silvi

Italian Group for the History of Solar Energy (GSES), Rome (Italy)

\section{Introduction}

This poster presentation is about the Italian contribution made over the last 200 years for the development of Concentrating Solar Thermal Power (CSP) with flat or almost flat reflectors.

The topic has been researched in the framework of the Italian Solar Energy History Project promoted by the Italian Group for the History of Solar Energy (GSES) and the Italian Committee "The History of Solar Energy." The ongoing research has been presented at ISES SWC (Silvi, 2003; Silvi, 2005), EuroSun Congress (Silvi, 2008), and Solar Paces Conference (Silvi, 2009).

Studies and experiments on burning mirrors and concentration of sunlight in Italy, in particular during the Renaissance period, are often cited in literature (Mirami, 1582; Bonaventura Cavalieri, 1632; Butti and Perlin, 1980). Lesser known, either nationally or internationally, are the Italian mathematicians, physicists, engineers, and scientists as well as their inventions and experiments aimed at producing steam and electricity from solar heat, carried out in the $19^{\text {th }}$ and $20^{\text {th }}$ centuries. This paper recalls two such inventors, who pioneered the CSP with flat or almost flat reflectors: Alessandro Battaglia (1842 - n.a.), whose work has been rediscovered by GSES in 2008, and Giovanni Francia (1911-1980), known as the father of solar thermoelectric plants, whose $100^{\text {th }}$ anniversary falls this year.

Fig. 1 shows the four common types of CSP, with curved reflectors - trough (a), and dish (c) - and with flat or almost flat reflectors - linear Fresnel (b), and tower (d).
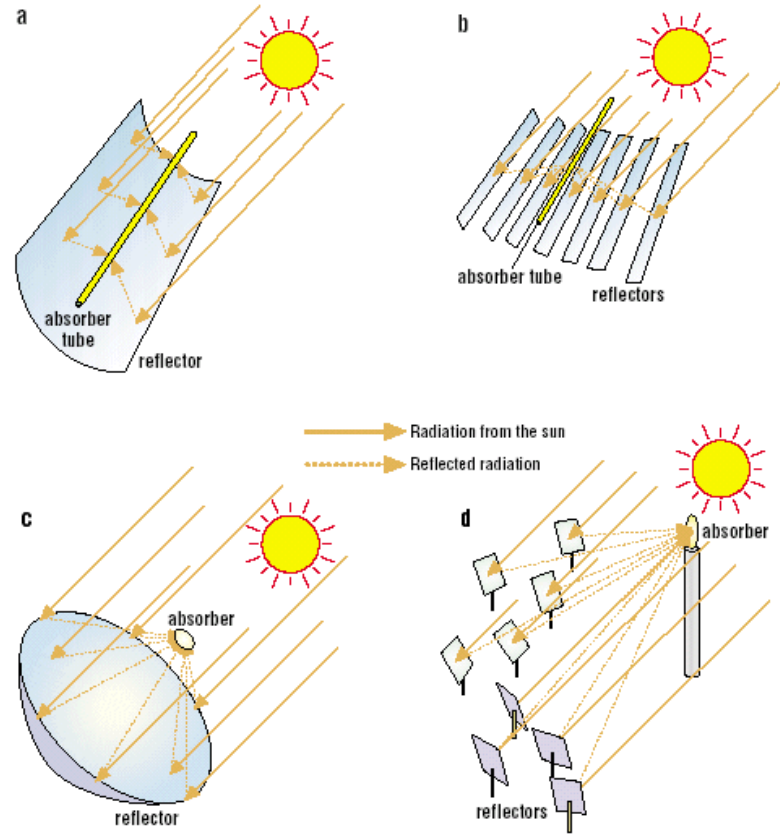

Fig. 1: Concentration of sunlight: a) Linear parabolic collector or trough; b) Linear Fresnel collector or Fresnel; c) Point focus parabolic spherical collector or dish d) Point focus Fresnel collector or tower. Source: http://www.solarpaces.org.

At present, the most established type of CSP plants in operation, under construction, and planned, is trough. Since early 2000, Linear Fresnel and Towers started to grow rapidly, promising to supply solar thermal electricity on a 
large scale and at lower cost than trough. This is another reason to take a closer look at the Italian history on CSP with flat or almost flat reflectors.

\section{Alessandro Battaglia (1842 - n.a.) and the "Collettore Multiplo Solare"}

\subsection{Mouchot, Pifre and Battaglia}

In 1860, Augustine Mouchot, a professor of mathematics at the Lycee de Tours in France, began to explore the possibility of transforming the sun's heat into mechanical energy. In his book "La Chaleur Solaire et ses Applications Industrielles", he observed:

"One must not believe, despite the silence of modern writings, that the idea of using heat for mechanical operations is recent. On the contrary, one must recognize that this idea is very ancient and in its slow development across the centuries it has given birth to various curious devices." (Mouchot, 1869).

In 1878 at the Universal Exposition in Paris Mouchot exhibited what is commonly known to be the first and largest machine in the world to produce solar steam. Mouchot's sun machine was subsequently improved by his assistant Abel Pifre, by adopting a spherical parabolic solar collector to power a printing press (Butti and Perlin, 1980).

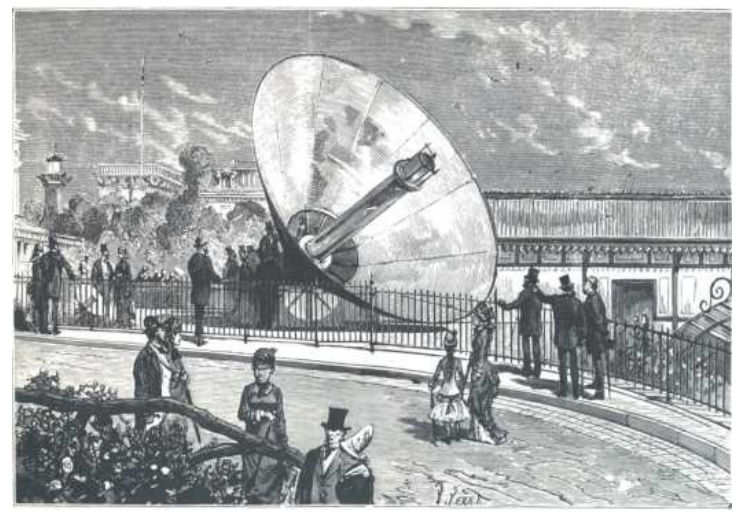

Fig. 2: Augustine Mouchot's sun machine, the largest of its time, on display at the Universal Exposition in Paris in 1878 (Butti and Perlin, 1980).

These developments in France were noted in Italy by Alessandro Battaglia (1842 - n.a.), an engineer born in Acqui Terme, where one of his ancestors had moved from Germignaga in the province of Varese during the 1700s.

Battaglia thought that the Mouchot-Pifre designs, despite their merits, also had several inherent limitations that he illustrated in 1884 at the Istituto di Incoraggiamento di Napoli (Encouragement Institute of Naples) with his paper "Sul modo e sulla convenienza di utilizzare il calore solare per le macchine a vapore" (On the methods and convenience of using solar heat for steam engines) (Semmola, 1884):

- It is not possible to build boilers of sufficient capacity to power industrial engines due to the fact that the boiler is mounted on the tracking collector, which limits its size;

- The boiler loses its heat easily because it is exposed to open air and cannot be insulated and protected;

- The tracking collector, as a single surface, is also limited in its total area.

\subsection{The "Collettore Solare Multiplo"}

To overcome these limitations, Battaglia proposed separating the boiler from the collecting reflector area. He proposed a horizontal cylindrical boiler, 30 meters in length and 1 meter in diameter, enclosed inside an insulating brick oven with a window of the same length as the boiler and 1 meter in height. The boiler faced a separate collecting reflector area made up of 1,250 small flat reflectors, one square meter each, distributed in 42 rows of 30 reflectors each. The system, which he described in economic and technical details, was estimated to have an output 
of $50 \mathrm{HP}(37.3 \mathrm{~kW})$, with an approximate cost of 100,000 lire in 1884 or the equivalent of 429,917 in 2010 Euros.

In 1884, Battaglia applied for a patent for his invention of a "Collettore multiplo solare" (Multiple Solar Collector), though with a boiler of just 10 meters and only 250 of the 1,250 flat reflectors indicated in his paper.

Battaglia's patent is illustrated in the following drawings, courtesy of the Central State Archive, Rome, Italy (Fig. $3)$.

The purpose of Battaglia's invention, as explained in his patent, is "to collect the solar rays that strike a specific portion of the earth's surface at any latitude, and to reflect them, concentrated in a specially shaped beam, onto a specific surface of limited size, in order to obtain a high temperature and a quantity of calories capable of causing a specific effect, at a cost relatively small for the size of the reflecting surface. The surfaces that receive and reflect the solar rays are metallic, silver-coated and burnished. The reflection must be continuous; that is, it must be aimed at the same point every day of the year, from sunrise to sunset." (Ministero Agricoltura e Industria, 1886).
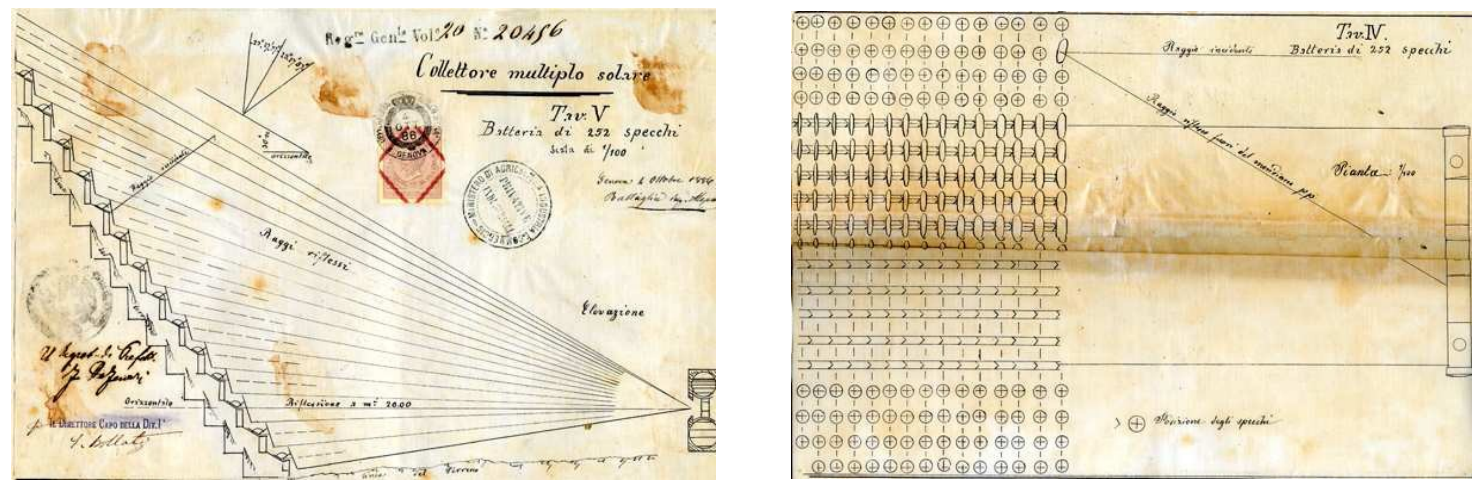

Fig. 3: Drawings from Battaglia's "Collettore multiplo solare" patent. Left, Cross section of the collecting reflector area and the longitudinal grounded boiler, one meter in height, installed inside a brick oven, insulating and protecting the boiler and with an opened window facing the reflector area. Right, Plan of the collecting reflector area and of the longitudinal or linear boiler, roughly ten meters in length. (Drawings, Central State Archive, Rome, Italy).

The Multiple Solar Collector was Battaglia's answer to the challenges of building large collectors, on which many scholars and scientists speculated during the 16th and the 17th centuries (Fig. 4).

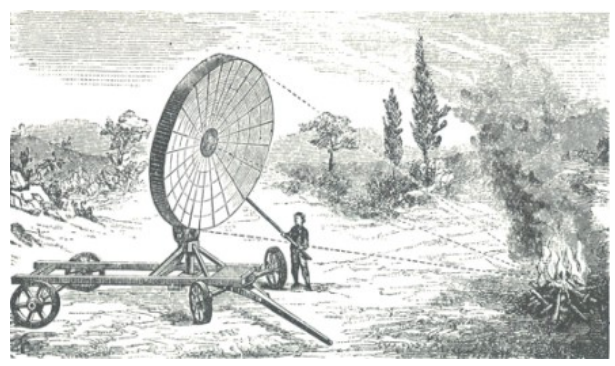

Fig. 4. A large burning mirror of the late 1700's built in sections (Butti and Perlin, 1980)

Battaglia's approach, which won him special recognition from the Istituto di Incoraggiamento di Napoli, overcame, in theory, some of the limitations in the Mouchot-Pifre designs, though there still remained obstacles, which had already been encountered in the past, as shown in the image above. As evident from the drawings in Battaglia's patent, the grounded boiler would require the reflectors to face downward and therefore be limited in the amount of sunrays they can capture and reflect toward the receiver.

In any event, Battaglia introduced new concepts, such as a longitudinal or linear receiver and a multiple reflector area made of many small and flat reflectors, each one tracking the sun independently. Both the reflector area and the boiler could therefore grow in size to collect large quantities of solar energy in order to meet modern industrial activities. 
Historical research on Battaglia's theories, as well as other work based on his patent registered on October 4, 1886, continue today. For example, research is being carried out to determine if Battaglia ever succeeded in building and testing a demonstration plant, as he was recommended to do by Semmola at the Istituto di Incoraggiamento di Napoli during his presentation in 1884.

\section{Giovanni Francia (1911 - 1980) and his solar inventions}

\subsection{Biographic note on Francia}

Born in Turin in 1911, Francia, the eldest of four children, grew up in the town of San Germano Chisone, near Turin. At 18, he lost his father and at the same time fell sick with tuberculosis. The disease forced him to drop out of engineering school and study on his own at the Agnelli sanatorium. In 1935 he was awarded his degree in mathematics. In 1938 he moved to Genoa, where he taught at the university and worked as a consultant. Starting in the 1950s, he produced many important inventions in various fields, such as motor vehicles, aircraft, space, textiles, and electro mechanics. From the 1960's and continuing until his death in 1980, he developed a special interest in solar energy and devoted most of his time to solar technologies (Silvi, 2005).

\subsection{Honeycomb structure and Francia's first solar boiler}

Francia thought that solar heat, abundant but at low density and low temperature, should be collected in such a way as to obtain the temperatures necessary to run the machinery used in technologically and industrially advanced societies, starting with electricity generators.

His first step toward raising the solar energy collection temperature was to invent the honeycomb structure, an array consisting of a large number of long, thin, parallel tubes made of glass, quartz or plastic. Being transparent to solar radiation but opaque to the heat rays emitted by the hot surface, the array served to reduce the collector's losses from re-irradiation and convection.
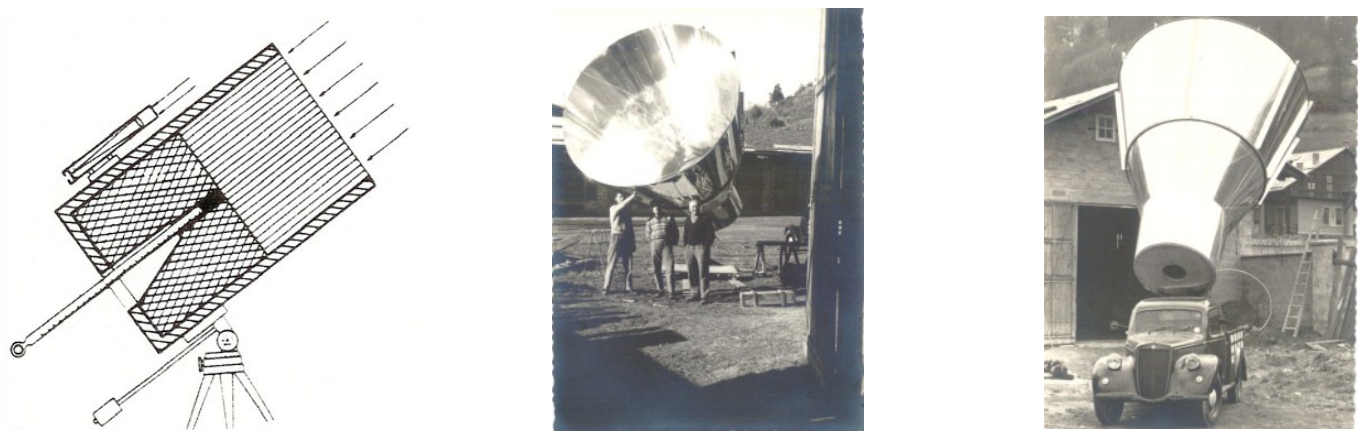

Fig. 5: Left: first honeycomb absorber that Francia built in 1960; Right: Photos of the first boiler coupled with a concentrator and protected by a honeycomb structure tested in Cesana Torinese in 1960/1961. To track the sun the boiler was moved by a small truck (photos 1960, Francia Archive, MUsil Brescia).

Fig. 5 shows the design for the first honeycomb system that Francia built in early 1960 for the sole purpose of testing the theory he was elaborating. In this case, the honeycomb was made up of hexagonal tubes $8 \mathrm{~mm}$ in diameter and $160 \mathrm{~mm}$ long. The device produced temperatures of $230-240^{\circ} \mathrm{C}$, far lower than the $500^{\circ} \mathrm{C}$ expected theoretically. Between 1960 and 1961, Francia continued experimenting with the design and built the first experimental solar station at Cesana Torinese. By coupling a concentrator with a boiler protected by a honeycomb structure made up of 2,000 thin glass tubes, Francia succeeded in reaching the temperature of $600^{\circ} \mathrm{C}$.

He then translated his honeycomb structure, theory and experimental results into his first solar patent (Italian patent no. 653295, May 5, 1961; extended to France and the United States), which he presented at the United Nations Conference on New Energy Sources (solar, wind, geothermal), held in Rome at the headquarters of FAO, the U.N. Food and Agriculture Organization, where he gained international recognition (Francia, 1961). At this Congress he 
met Marcel Perrot (1908-2006) of the Solar Research Group of the University of Marseille (France), with whom he started a fruitful cooperation in solar energy.

\subsection{Concentration of Sunlight with flat or almost flat reflectors}

Before Francia came on the stage, the Fresnel reflector concept (in a Fresnel reflector a smooth optical surface is broken into many segmented optical surfaces) was studied in Italy, as shown above, by Alessandro Battaglia. Abroad the most significant work was done in the Soviet Union by Valentin A. Baum (Fig. 6).

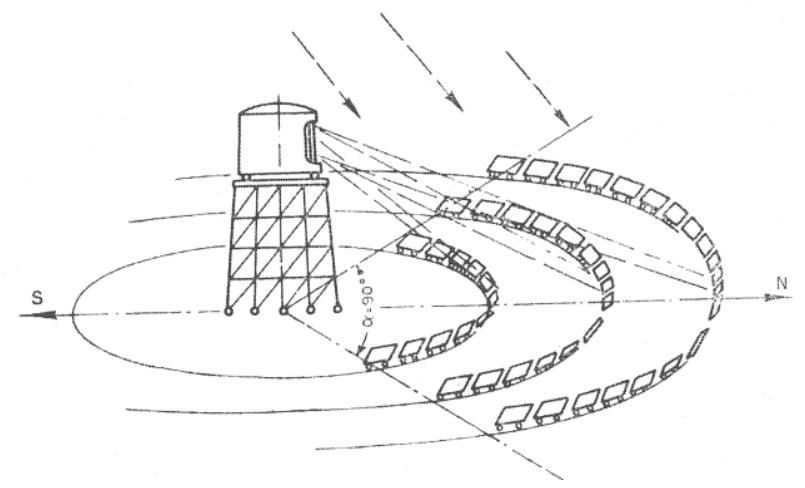

Fig. 6: Solar Tower designed by V.A. Baum. Reflectors track the sun by moving on concentric rails around the tower where the boiler is mounted (Baum, 1956).

Francia, who was apparently unaware of Alessandro Battaglia's work, followed nonetheless the same conceptual path: separating the reflector from the boiler. Between 1962 and 1965, he designed, built, and tested the first real linear and point focus Fresnel reflector concentrators, LFCs and PFCs (Fig. 1), demonstrating that it is possible to produce steam at high pressures and temperatures with solar heat. He presented the results of his work in the 1968 issue of the Solar Energy Journal (Francia, 1968).

From the very start Francia envisioned a new architecture for future concentrating type solar plants different from those experimented with most up till then.

In a letter dated January 17, 1962, to a French colleague, who had suggested using linear parabolic reflectors in his pioneering plant at Marseilles (France), that had already been tested in the United States by Boeing, Francia replied, "large solar plants can only be built with flat reflectors" (Letter by Touchais, Dec. 1961; Letter by Francia, Jan.1962).

\subsubsection{Linear Fresnel Reflector Concentrator}

Francia filed his first LFC patent in 1962 (Italian patent, no. 6788664, Nov. 23, 1962; extended to France and the United States). The next year, he designed and built the first LFC prototype, in Genoa, and in 1964 he reassembled and tested it at the Lacédémone-Marseilles solar station, in cooperation with Marcel Perrot, and with support from France's National Research Council (CNRS), NATO and COMPLES (Coopération Méditerranée pour l'Energie Solaire) (Fig. 7).

As described in a note "Solar Power Plant Francia's Type," February 14, 1963, in Francia's archives, this first LFC was built with the cooperation of GRESUMG (Gruppo Ricerca Energia Solare Università Marsiglia Genova - Solar Energy Research Group, Marseilles and Genoa Universities) and stood on an area of approximately $8.2 \times 7.9 \mathrm{~m}^{2}$. It had 7 aluminum reflectors, 8 meters long and 1 meter wide, parallel to each other on an east-west line. Each mirror rotated around its lengthwise axis, concentrating solar radiation on a linear boiler positioned parallel to the reflectors at a height of about 6 meters. The rotary motion was the same for all the reflectors, and was obtained by means of an electronic command guided by the sun itself. The boiler was slightly less than 8 meters long and 25 centimeters wide. It was protected on the front (the side facing the reflectors) by the honeycomb structure and on the back by appropriate insulation and a lost heat - recovery device. 

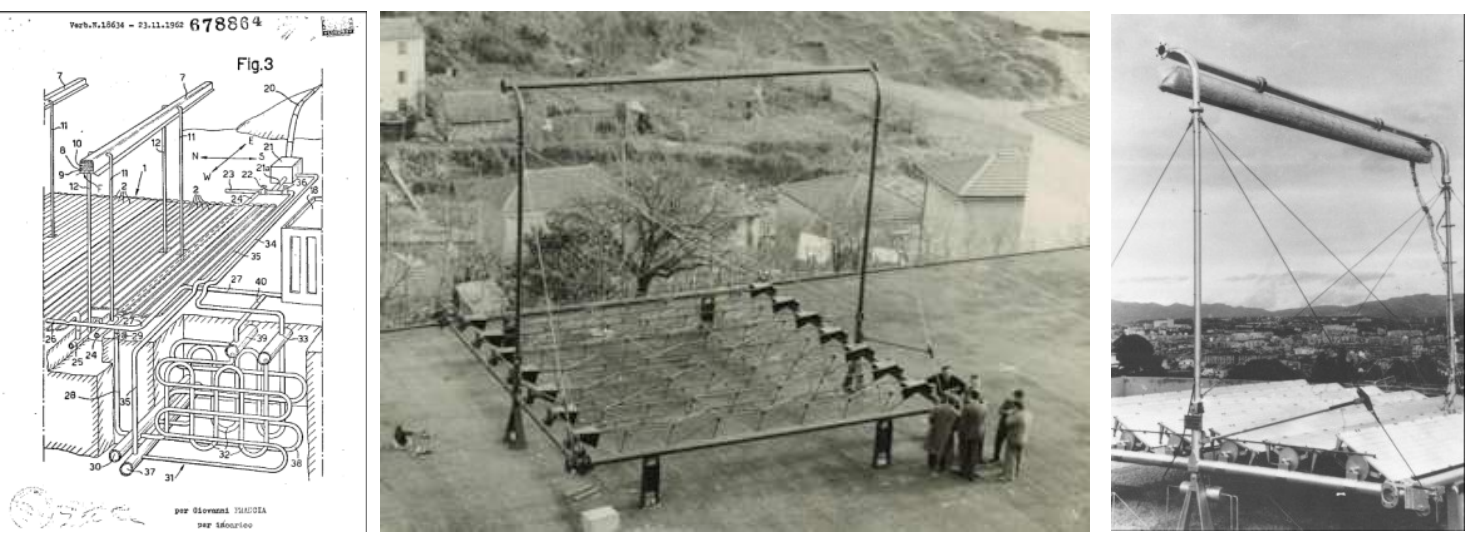

Fig. 7: World's first linear Fresnel concentration-type solar plant, built and tested at Marseilles (France) in 1963/1964. Left: drawing of the patented LFC; Right: Photos of Francia's first LFC prototype (Francia Archive, Museum of Industry and Work, MUsil, Brescia, Italy).

Two flat vertical reflectors limited energy loss on the west side in the morning and on the east side in the afternoon; otherwise, reflected energy would reach the boiler only during the midday hours, due to the short length of the reflectors. In the design for the large solar plant described in Francia's patent no. 18634, of which the Marseilles plant was the first unit, the aluminum-mirror strips were much longer than the boiler is high, which eliminated the need of protective reflectors on the sides. Likewise, the Marseilles unit was designed to be scalable; the length of the strips of reflectors could be tripled or quadrupled and their number increased. The plant was built with off-the-shelf materials in order to simplify the construction and reduce costs, with the idea to perfect them based on the experimental results obtained with the prototype. The plant generated $38 \mathrm{~kg} / \mathrm{h}$ of steam at $100 \mathrm{~atm}$ and $450^{\circ} \mathrm{C}$.

The plant was expected to supply around 1,200 thermal $\mathrm{kWh}$ annually per square meter of reflectors in Marseille, making a total of $67,200 \mathrm{kWh}$ per year. If the plant had been built in Sicily, Francia calculated that production would have reached 1,600 kWh per year per square meter, for a total of $89,600 \mathrm{kWh}$ annually. According to Francia's evaluation at the time, with a large-scale plant, the power output could be much cheaper per kWh than that generated from petroleum.

The drawings in Fig. 8 and Fig. 9 show Francia's vision of a large LFC integrated in urban and rural contexts.
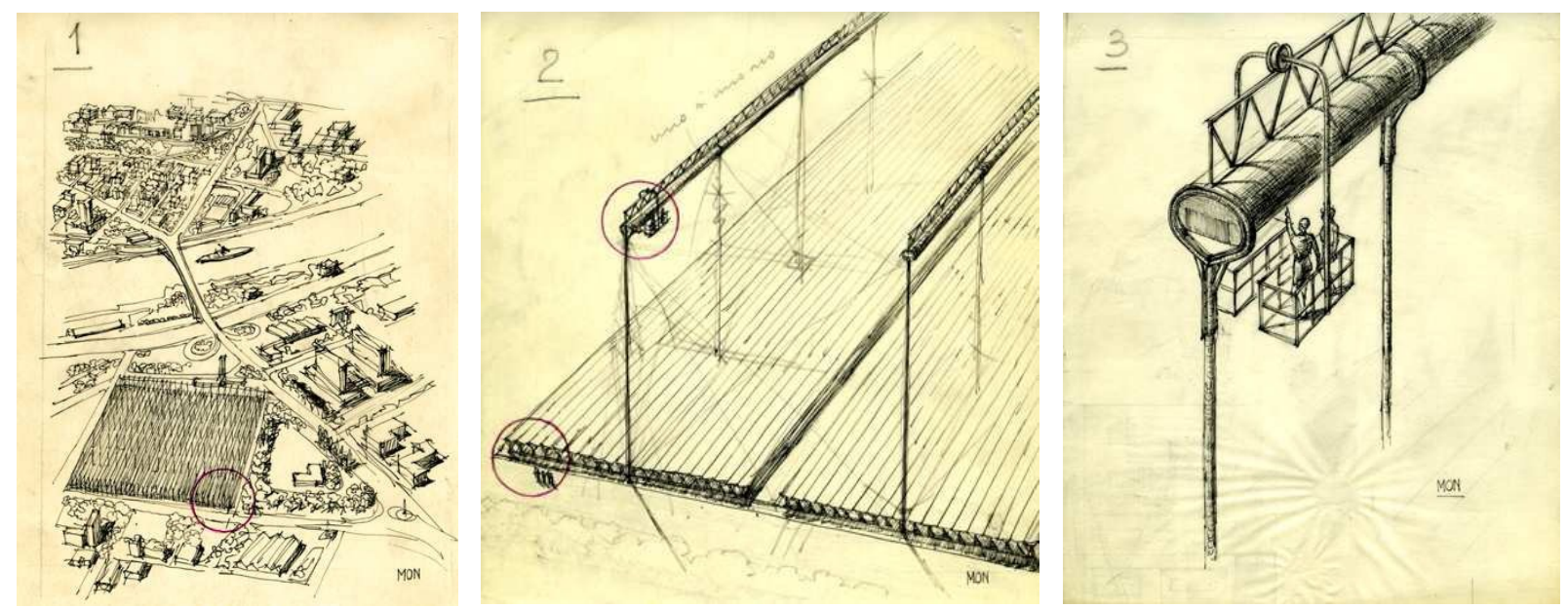

Fig. 8: Francia's drawings of the envisioned large solar LFC power plant integrated in an urban context of circa 1965 (Francia Archive, Museum of Industry and Work, MUsil Brescia, Italy). 


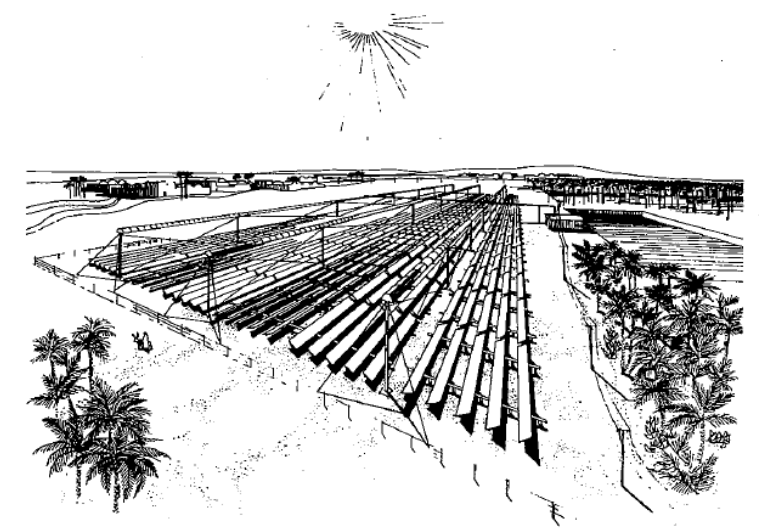

Fig. 9 - Artist's rendering of an LFC solar power plant designed by Giovanni Francia and collaborators in the late 1970s (Ansaldo Meccanico Nucleare, 1980).

\subsubsection{Point focus Fresnel Reflector Concentrator or solar tower}

Francia believed that solar energy would become competitive for power generation only when solar boilers were improved to the point when they could produce steam at pressures above 150 atmospheres and temperatures above $500^{\circ} \mathrm{C}$, a goal that seemed more likely achievable with solar towers than with linear concentration systems at the time.

Therefore, he put LFC technology on the back burner and began focusing mainly on point-focus, central or towermounted receivers or solar towers. In 1965 built the first PFC at the Sant'Ilario solar station near Genova, which supplied $21 \mathrm{~kg} / \mathrm{h}$ of steam at $150 \mathrm{~atm}$ and $500^{\circ} \mathrm{C}$ (Fig.10).
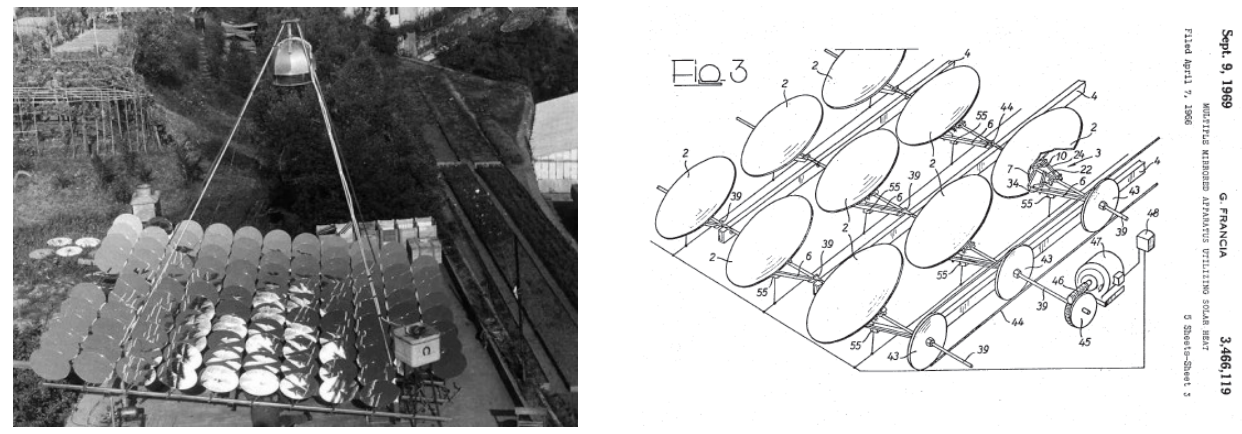

Fig. 10: Left: World's first point-focus Fresnel reflector concentrator or solar tower, built and tested at Sant'Ilario, in the township of Nervi, near Genoa (Italy), in 1965 (Francia Archive, MUsil Brescia). Right: Francia's solar tower patent filed in USA in 1966 (Digitized by Google).

In the following years he built and perfected three additional solar tower prototypes $(1967,1972,1978)$.

In 1973 his work was noted by major industrial concerns that requested his advice for the construction of industrialscale demonstration plants. Francia was involved in the $400 \mathrm{kWth}$ Solar Thermal Facility at the Georgia Technology Institute in the US that started operation in 1977 and the 1 MWe Eurelios power plant at Adrano, Sicily, in Italy, that became operational in April 1981.

Eurelios was the world's first large-scale demonstration power tower to be connected to a national power grid (Fig. 11). It was built, under the supervision of the Commission of the European Communities, by an industrial consortium consisting of ENEL and ANSALDO - Italy, CHETEL - France, and MBB - F.R. Germany.

The Eurelios tests were completed in 1985, and ENEL published the results in 1991. The authors of the report concluded that the per-kWh cost of electricity generated by Eurelios would be far from acceptable even if the upfront costs of the plant were reduced. The report ended with this statement: "This conclusion, which is shared by the 
great majority of world experts, leads us to think that tower and mirror-field solar plants will not give rise, even in the medium and long term, to industrial applications of any importance” (ENEL, 1991).

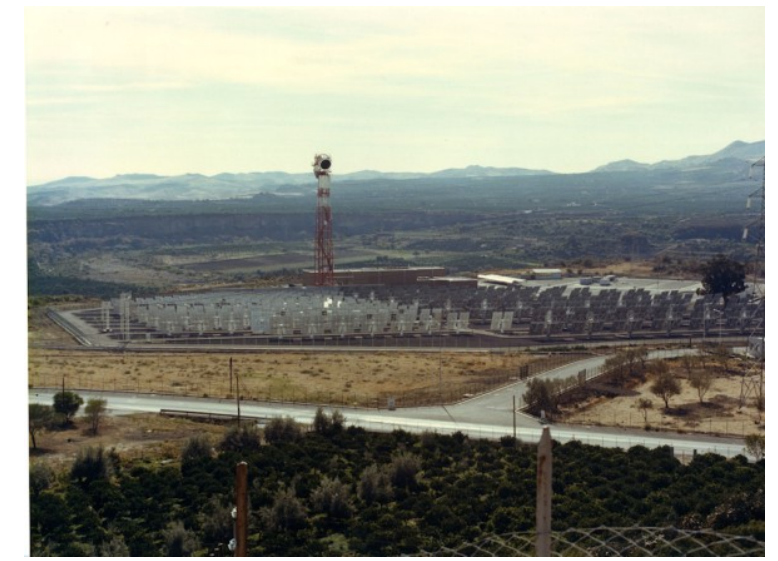

Fig. 11: The Eurelios plant, view of the heliostat field and the boiler tower, photo 1982, Parodi archive.

Several factors, including Giovanni Francia's death, in 1980, ENEL's conclusions regarding Eurelios, falling fossil fuel prices, and, in the United States, the advent in 1981 of Ronald Reagan's presidency, which substantially changed the nation's energy policy from that of the Carter administration, with inevitable effects on the energy policies of other countries as well, led to a general reluctance to pursue solar energy in general. In Italy, in particular, skepticism blocked progress with regards to point-focus or tower concentrating plants, which Francia pioneered, while further development continued worldwide.

At the beginning of 2011 Eurelios was dismantled. On initiative of the Italian Group for the History of Solar energy, the remains of the boiler were donated by ENEL to the Museum of Industry and Work (MUsil) in Brescia, Italy, in March 2011 (Fig. 12).

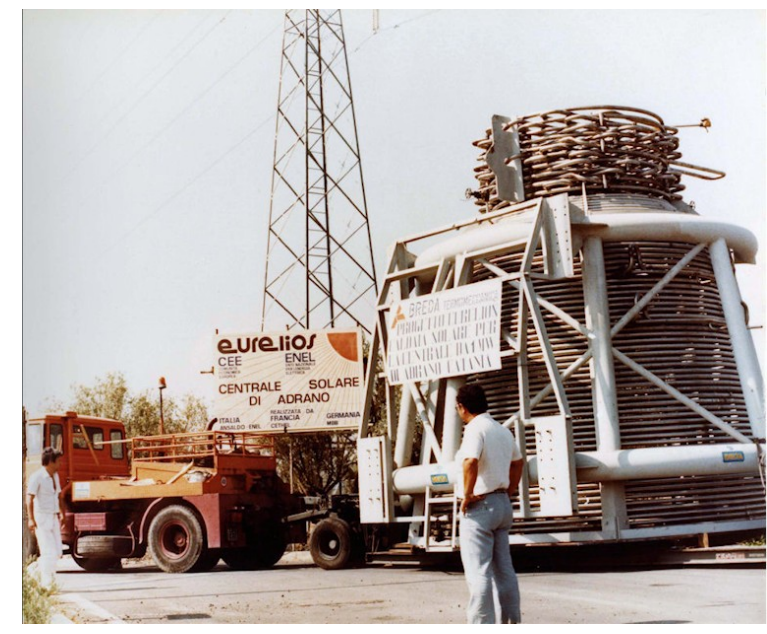

Fig. 12: Eurelios' solar boiler before its installation on the top of the tower, photo 1980, MUsil, Brescia, Italy.

\section{Developments of CSP with flat or almost flat reflectors in the world today}

Solar radiation (direct and diffused) is the largest energy resource on Earth $(\sim 3,000,000$ EJ). Today, it contributes to the production of electricity with solar photovoltaic systems in about 30,000 MW and 1,000 MW in CSP plants.

Table 1 reports type and power capacity of world CSP plants in operation, under construction, and planned in 2010 (Gestuizen, 2010). 
Tab. 1: World CSP plants in 2010.

\begin{tabular}{|c|c|c|c|c|c|}
\hline \multicolumn{6}{|c|}{ WORLD CSP IN 2010 - PLANT CAPACITY (MW) AND PERCENT (\%) } \\
\hline REFLECTOR & \multicolumn{2}{|c|}{ CURVED REFLECTOR } & \multicolumn{2}{|c|}{ FLAT REFLECTOR } & \multirow{2}{*}{ TOTAL MW } \\
\hline PLANT TYPE & TROUGH & DISH & LINEAR FRESNEL & TOWER & \\
\hline $\begin{array}{l}\text { PLANTS } \\
\text { IN } \\
\text { OPERATION }\end{array}$ & $\begin{array}{c}767.16 \\
94 \%\end{array}$ & $\stackrel{1.65}{\sim}$ & $\begin{array}{c}9.40 \\
1 \%\end{array}$ & $\begin{array}{c}42.40 \\
5 \%\end{array}$ & 820.00 \\
\hline $\begin{array}{l}\text { PLANTS } \\
\text { UNDER } \\
\text { CONSTRUCTION }\end{array}$ & $\begin{array}{c}1,759.22 \\
97 \%\end{array}$ & $\stackrel{1.01}{\sim}$ & $\begin{array}{c}30.00 \\
2 \%\end{array}$ & $\begin{array}{c}17.00 \\
1 \%\end{array}$ & $1,800.00$ \\
\hline $\begin{array}{l}\text { PLANTS } \\
\text { PLANNED }\end{array}$ & $\begin{array}{c}7,850.00 \\
66 \%\end{array}$ & $\begin{array}{c}2,247.00 \\
19 \%\end{array}$ & $\begin{array}{c}134.00 \\
1 \%\end{array}$ & $\begin{array}{c}1,600.00 \\
14 \%\end{array}$ & $14,500.00$ \\
\hline
\end{tabular}

In theory, Linear Fresnel and Tower with flat reflector technology, adopted in large plants, promise to produce electricity at higher efficiencies than troughs. For example, the conversion solar/electric is estimated $20 \%$ for tower compared to $14 \%$ for trough and mirror field cost is $160 \$ / \mathrm{m}^{2}$ for tower as opposed to $250 \$ / \mathrm{m}^{2}$ for trough (Biancalana, 2011). The true test will come only after large plants, currently under construction by companies such as BrightSource Energy and Areva Solar, are operational (Fig.13).
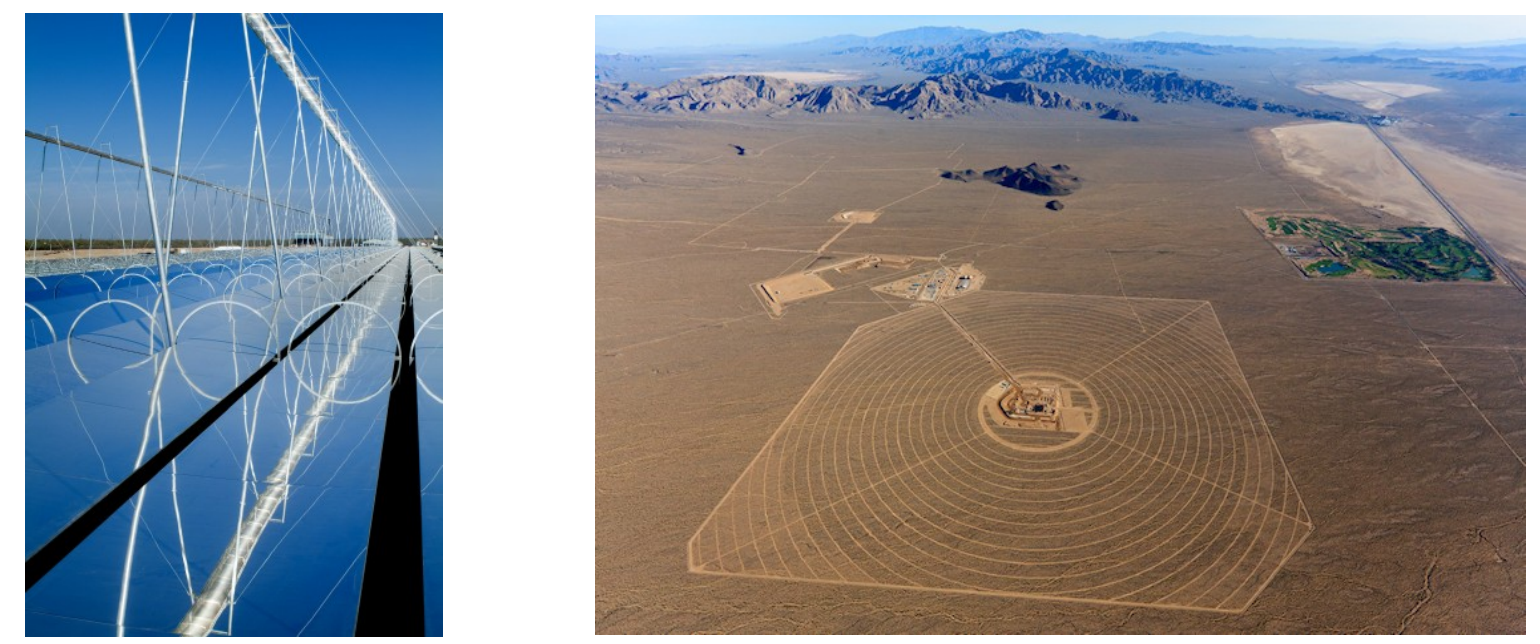

Fig. 13: Left: Compact Linear Fresnel Reflector (CLFR) developed by Ausra now Areva Solar, photo 2009, courtesy of Ausra. Right: An aerial view of the first unit (120 MW) out of three (392 MW), of the BrightSource Energy Solar Electric Generating System, under construction in California at Ivanpah, photo 2011, courtesy of BrightSource Energy.

However, the principal competition is not among CSP technologies but that created by improvements in efficiencies and reduced costs of photovoltaic technology (PV). These improvements have resulted in rapid growth in recent years leading lenders and investors to focus on major photovoltaic projects rather than CSP. In just the first few months of 2011, CSP projects on the order of 1,850 MW already planned in California have been transformed in photovoltaic plants (Groom, 2011). For some experts, this trend might even bring about the end of CSP, a topic that merits a separate paper and is not in the scope of this presentation. 


\section{Conclusions}

Is CSP with flat or almost flat reflectors among the technologies that will supply electricity on a large scale in the modern solar age?

To answer this question, one should consider the thoughts of a visionary, Hanns Günther, who published in 1931 a book entitled "In a hundred years: the world's future energy supply" (Günther, 1931). In his book, Günther provides an overview of all possible energy sources and technologies suitable to confront the depletion of coal reserves: from large wind towers, to wave power stations, thermoelectric and photoelectric systems, fuel cells and atomic batteries. He imagines that in one hundred years, i.e. in 2031, technological advances in the production of electricity would end the "vicious circle through the boiler, steam turbine and generator of electricity."

The discovery of the photovoltaic cell in 1954 has effectively already opened the way for the possibility of Günther's idea to become a reality one day.

He does not give much importance to concentrating solar thermal power technologies, which he judged as "lamentable attempts, using expensive optical means, of those who want to heat a small boiler by concentrating sunlight on it."

For Günter one day mankind might laugh at "the huge thermal and hydraulic plants which provide electricity to man today." He predicted that "instead of satisfying the voracity of giant boilers with precious fuels such as coal and oil, or rather than building numerous dams, new small machines able to release atomic energy will be built, with the result that their power will exceed by thousands of times that of their predecessors. At that point everything related to the transport of fuel from one part of the Earth to the other will disappear, given that the annual needs of a power plant may be contained in a bottle, and therefore electricity will be used everywhere for all types of work."

Currently the atomic bottle envisioned by Günter is not yet on the horizon (nuclear reactors at low energy?). On the contrary CSP solar thermal storage and photovoltaic battery technology are rapidly developing in combination with swift progress in efficiency as well as falling costs of solar electricity. For now the only bottle in sight is therefore a "solar bottle," photovoltaic or CSP.

\section{References}

Ansaldo Meccanico Nucleare, CESEN, Ansaldo, 1980. Solar Energy Exploitation: High and Medium Temperature Thermodynamic Conversion, Genoa (Castellazzi Archive).

Baum, V.A., 1956. Prospects for the application of solar energy, and some research in the USSR, Proceedings of the World Symposium on Applied Solar Energy, Stanford Research Institute, Menlo Park, California, 289-298.

Biancalana, F.M., 2011. In costruzione in California il più grande impianto solare del mondo con torre e specchi piani: il contributo italiano alla caldaia solare. Ingegneria Ambientale, Anno XL N. 1 gennaio-febbraio, 4-8.

Bonventura Cavalieri, F., 1632. Lo specchio ustorio ovvero trattato delle Settioni coniche... , Clemente Ferroni, Bologna, Italia.

Butti, K., Perlin, J., 1980. A Golden Thread - 2500 years of Solar Architecture and Technology, Cheshire Books, Palo Alto, CA USA.

Francia, G., 1961. Un nouveau collecteur de l'énergie rayonnante solaire. Théorie et verifications expérimentales, E/Conf. 35/S/71, United Nations Conference on New Energy Sources. Roma, 1961 (E/Conf. 35/5, pp. 554-588).

Francia, G., 1968. Pilot Plants of Solar Steam Generation Systems. Solar Energy Journal. 12, 51-64.

Gesthuizen, J., 2010. CSP, World map of power stations, Sun \& Wind Energy 6/2010, $94-100$.

Groom, N., 2011. Solar developers scrapping thermal for photovoltaic, www.reuters.com/article/2011/06/30/us- 
solar-switch-idUSTRE75T60X20110630, published June 30, 2011; last accessed August 13, 2011.

Günther, H., 1931. In a hundred years: the world's future energy supply, Kosmos, Gesellschaft der Naturfreunde, Franckh'sche Verlagshandlung, Stuttgart.

ENEL, 1991. Progetto Eurelios. Utilizzazione dell'energia solare in impianti elio termoelettrici.

Ministero Agricoltura e Industria, 1886. Certificate of industrial patent (13 October 1886, Vol.40, no 412) valid for three years from 30 September 1886, issued to Mr. Alessandro Battaglia in Genoa for a device called Multiple Solar Collector.

Mirami, R., 1582. Compendiosa introduttione alla prima parte della specularia... in Ferrara, Appresso gli heredi di Francesco Rossi \& Paolo Tortorino compagni, Ferrara, Italia.

Mouchot, A., 1869. La Chaleur Solaire et Ses Applications Industrielles, Gauthier Villar, Imprimeur Libraire, Paris.

Semmola, E., 1884. Report on the submitted paper by engineer Mr. Alessandro Battaglia "On the mode and the convenience of using sun's heat," read by Professor Eugenio Semmola, session of the 17th of April 1884, Proceedings of the Institute for Encouragement of Naples.

Silvi, C., 2003. Can the History of Energy Technology and Use Educate us for a Solar Energy future? The Italian Case, ISREE-9 Proceedings ISES Solar World Congress 2003, Göteborg, Sweden.

Silvi, C., 2005. The work of the Italian solar energy pioneer Giovanni Francia (1911-1980), Proceedings ISES Solar World Congress 2005, Orlando Florida, USA.

Silvi, C., 2008. Italy's Archive on the History of Solar Energy, Poster Presentation, Proceedings EuroSun 2008, Lisbon, Portugal.

Silvi, C., 2009. The Pioneering Work on Linear Fresnel Reflector Concentrators (LFRs) in Italy. Proceedings of the SolarPaces conference, Berlin, Germany, Sept. 15-18, 2009. 